Milan Mihajlović ${ }^{1}$

Jelena Tadić ${ }^{2}$

Jelena Jotic ${ }^{3}$

Univerzitet Edukons, Fakultet poslovne ekonomije
ORIGINAL SCIENTIFIC ARTICLE

DOI: 10.5937/ekonomika2103063M

Received: March, 05. 2021.

Accepted: Jun, 16. 2021.

\title{
IMPLEMENTATION OF QUALITY MANAGEMENT SYSTEM AND THE LEVEL OF MATURITY OF THE COMPANY IN THE DAIRY INDUSTRY OF SERBIA
}

\begin{abstract}
The aim of this paper is to point out the existence of differences in the application of quality management systems as well as the level of maturity in the companies of the dairy industry in the Republic of Serbia. The initial assumption is based on the defined goal which states that the application of quality management systems and the level of maturity in these companies differ depending on their size. The research was conducted on the basis of QMMG - Quality Management Maturity Grid model of maturity. The initial assumption test was performed using the Kruskal-Wallis test as a nonparametric alternative to one-way analysis of variance of different groups. In addition to this method, the methods analysis, the synthesis method and descriptive statistics were also used. Using the mentioned statistical methods, six aspects of the quality management system were processed (Management understanding and attitude, Quality organisation status, Problem handling, Cost of quality as percent of sales, Quality improvement actions and Summary of company quality posture) as well as the entire quality management system in selected companies. Statistically significant deviations were found in five of the six aspects as well as in the overall quality management system. The contribution of this research is reflected in the diagnosis of the level of maturity in the companies covered by this research together with the possibility of improving certain aspects of the quality management system in order to develop the skills needed to increase the companies' quality performance.
\end{abstract}

Key words: quality management, maturity models, company performance

JEL classification: L15, M11, O33

\section{ИМПЛЕМЕНТАЦИЈА СИСТЕМА УПРАВЉАҢА КВАЛИТЕТОМ И НИВО ЗРЕЛОСТИ ПРЕДУЗЕЪА У ИНДУСТРИЈИ МЛЕКА У РЕПУБЛИЦИ СРБИЈИ}

\footnotetext{
Апстракт

Основни цииь овог научног рада је да се укаже на постојағе разлика у примени система управљања квалитетом као и нивоа зрелости у предузећима индустрије

${ }^{1}$ mihamilan@gmail.com ORCID 0000-0001-6472-5973

2ajelena83@gmail.com ORCID 0000-0003-1369-6329

3 jelenajotic@gmail.com ORCID 0000-0002-4755-5930
} 
млека у Републици Србији. На основу постављеног ичиља дефинисана је полазна претпоставка да се примена система управљања квалитетом и ниво зрелости у овим предузећима разликује у зависности од юихове величине. Истражсивағе је спроведено на основу QMMG - Quality Management Maturity Grid модела зрелости. Испитивање полазне претпоставке извриено је применом Крускал-Валисовог теста као непараметарске алтернативе једносмерној анализи варијансе различитих група. Поред ове методе коришћене суиметод анализе, метод синтезе и дескриптивне статистике. Помоћу наведених статистичких нетода обрађено је шест аспеката система управљања квалитетом (разумевање управљања квалитетом, статус квалитета организачије, решавање проблема, трошкови квалитета као \% од продаје, активности побољшаға квалитета и резиме става компаније о квалитету) као и целокупан систем управљања квалитетом у изабраним предузећима. Утврђена су статистички значајна одступаға у пет од шест аспеката као и у целокупном систему управљања квалитетом. Допринос овог истраживања огледа се у дијагностификовању нивоа зрелости у предузећима обухваћеним истраживањем као и могућности унапређења појединих аспеката система управљаға квалитетом како би се развиле способности потребне за повећање квалитета пословања.

Кључне речи: управљање квалитетом, модели зрелости, перформансе предузећа

\section{Introduction}

The concept of quality management is based on a management philosophy that is guided by the expectations and requirements of consumers, in other words the market. An efficient quality management system is required to consistently provide products and services that meet user requirements as well as all stakeholder requirements, which in business world today imposes the need for continuous quality improvement of products and services.

An important pillar of quality management is standardization which is the basis for ensuring a quality system in each business system and the economy as a whole. Therefore, when it comes to quality, we always start from the assumption that the issue of standardization has been previously resolved, because it is considered that it is not possible to provide quality without the existence of appropriate standards. Most countries around the world today apply quality management systems based on the International Organization for Standardization (ISO). The most common are certainly the standards from the 9000 series, but also many other standards of this organization ISO 14001, ISO 45000, ISO 22000, ISO 26000, etc.

The standards of this organization were created on the basis of international experience in different areas of business and thus provide systematic quality improvement in all companies to implement them in business. Acceptance of these standards also means a simpler comparison of the experiences of companies around the world and find a solution for any shortcomings in the work. (Stepanov S, et al 2017, p. 83-96)

Standard ISO 9001:2015, as well as previous versions, is based on the process approach. The emphasis is on the adoption of the process approach in all segments of organisation management which improves effectiveness and efficiency of the quality system management 
and thus fulfills users' needs and demands and increases their satisfaction. It is essential to understand interrelated processes within a system and their management that are defined by quality politics and strategic direction of the organisation. (Mihajlović M, 2018 p 221-238)

By establishing a quality management system based on a series of ISO standards the foundations has been laid which has created the conditions for standardization that enables the comparison between organizations as well as monitoring the performance of the organization over time. However, it is very important to point out that obtaining a quality management system certificate from the group of ISO standards is not enough for the great achievements of the organization because a certified quality management system serves only as a good basis for its further improvement.

Continuous improvement is a very important factor in the process of certifying and maintaining the quality management system (Valadao A. F. C. et al 2013 p 96-110.) By providing continuous improvement of quality, it is necessary to develop a set of planned activities for improving the functioning of the organization, which are directly related to its systematic review and evaluation.

As a very good means of continuous improvement of business quality, maturity models have appeared, on the basis of which the level of maturity of the quality management system in a certain organization is assessed. Maturity models allow organizations to accurately identify strengths and weaknesses as well as areas that need improvement in a particular case.

Maturity models show the evolution of an enterprise through individual stages on its way to increase the performance quality and their main purpose is to describe the phases and ways of the company's mature growth. When it comes to their application in practice, maturity models make it easier to identify the gap between the current and desired level of maturity, as well as the abilities that need to be improved to bridge this gap. Therefore, it can be said that their purpose is to diagnose and develop the skills needed to increase the quality performance.

In order to point out the existence of differences in the application of the quality management system as well as the difference in the level of maturity, this paper presents a research conducted in the enterprises of the dairy industry in the Republic of Serbia. The research was conducted on a stratified sample of 14 companies. The representativeness of the sample was ensured on the basis of selection criteria for the companies covered by the research, such as: the importance of individual market participants, installed production capacities, their position in regional market segments as well as the number of employees.

In accordance with the aim of the research, the initial assumption was defined

H1: The implementation of the quality management system and the level of maturity in the dairy industry vary by company size.

which was examined using the QMMG model of maturity and statistical analysis of the data obtained by the research. The results of the statistical analysis showed significant deviations in the implementation of the quality management system and therefore the level of maturity.

\section{Literature Review}

Companies are constantly looking for ways to improve their business while striving to achieve business excellence at the same time. As achieving excellence in a dynamic, global environment is very challenging, many authors have developed and proposed maturity models with the intention of facilitating the gradual improvement of the quality performance. 
One of the first maturity models was created by Philip Crosby. The Quality Management Maturity Grid - QMMG was published in 1979 in his famous work "Quality is free" (Crosby, 1979). It is aimed for companies or organizations as an indicator of how mature their processes are and how well they are embedded in their culture, given the management of the quality of services or products. The success of the application of this maturity model has served many authors in creating their own maturity models for validation and measurement of quality management.

- World-Class manufacturing (Schonberger R., 1986)

- The reliability and validity of eight critical factors of quality management (Saraph, J.V, et. al. 1989 p 810-829.)

- $\quad$ Seven key dimensions of quality management (Flynn, B.B, et. al. 1994 p 339-366.)

- Identifying seven underlying dimensions of quality management based on 14 Points of Deming (Anderson, J.C, et. al. 1995 p 637-658)

Over time, due to the unequal view of TQM, Business Excellence Models - BEMs have been developed. These models are created based on the TQM methodology and contain criteria by which the level of business excellence that the organization has achieved is assessed. The diversity of criteria for business excellence models, although they represent the operationalization and quantification of TQM elements, is conditioned by the cultural, technological, organizational and socio-economic characteristics of a particular country, its companies, organizations and people. Each criterion is broken down into a number of sub-criteria whose application, both vertically through all levels of the organization's business functions as well as horizontally in all areas and processes, is examined and evaluated. In this way, not only is the general level of business excellence of the organization determined, but also the possibilities for improving business performance are realized.

Business Excellence Models (BEMs)

- The Malcolm Baldrige National Quality Award - MBNQA (1988)

- Shingo Prize (1988)

- HKMA - Quality Award in Hong Kong (1991)

- European Foundation for Quality Management (EFQM) - Excellence Model (1992)

- The Japan Quality Award (1996)

Quality management maturity models represent the operationalization of process orientation. In that sense, they contain a number of elements which level of maturity (development, quality) should be measured, monitored and improved, in order to increase the level of maturity of quality management. Given the number of maturity models of process management, it is not logical to expect their authors to agree on the level of maturity or number of stages that the company goes through on its path of implementation and development of process management. Hence the number of models is not surprising

- $\quad$ Business Process Management Maturity (BPMM) model (Rosemann M., \& de Bruin T., 2004)

- $\quad$ The Process Performance Index (Rummler-Brache Group, 2004)

- Maturity of Business Process Re-engineering (BPR) programmes (Maull R. S., et. al. 2003 p 596-624)

- The Business Process Maturity Model (Fisher D., 2004 p 11-15).

- $\quad$ Process Management Maturity Assessment PMMA (Rohloff M. 2009). 
- $\quad$ Business Process Orientation (BPO) maturity model (McCormack K., 2007)

- $\quad$ Process and Enterprise Maturity Model PEMM (Hammer M., 2007 p 111-123).

- Evaluating Business Process Maturity (Harmon P., 2004 p 1-11).

- Business Process Maturity Model version 1.0. (Weber C., et. al. 2008)

- Business Process Maturity Model (BPMM) for measuring and improving business process competence. (Lee, et.al. 2007)

However, all models certainly include phases that follow a logical sequence that shows improvement in business process management practice, so that the results and achievements of one phase or achieved at one level are the basis for the transition to a higher level of maturity.

For the purpose of this research which results are presented in this paper, one of the best known and most applied models was taken into consideration, Crosby's Quality Management Maturity Grid - QMMG, which can be used to determine, simply, the stage of quality management maturity in a particular company.

Crosby Matrix 5x6 shows the different stages of a company's quality management maturity in relation to six different categories of quality management (Quality management understanding and attitude, Quality organisation status, Problem handling, Cost of quality as \% of sales, Quality improvement actions, Summary of company quality posture). Depending on the stage of implementation of quality management, the maturity of the company is determined, which Crosby divided into five phases (Crosby, 1979):

- Uncertainity,

- Awakening,

- Englightenment,

- Wisdom,

- Certainity.

Table 1: Quality Management Maturity Grid-QMMG

\begin{tabular}{|c|c|c|c|c|c|}
\hline \multicolumn{4}{|c|}{ Quality Management Maturity Grid (Crosby) Assessor } & \multicolumn{2}{|c|}{ Department } \\
\hline $\begin{array}{l}\text { Measurement } \\
\text { Categories }\end{array}$ & \begin{tabular}{|l|} 
Stage 1: \\
Uncertainty \\
\end{tabular} & \begin{tabular}{|l|} 
Stage 2: \\
Awakening \\
\end{tabular} & \begin{tabular}{|l|} 
Stage 3: \\
Enlightenment \\
\end{tabular} & Stage 4: Wisdom & \begin{tabular}{|l|} 
Stage 5: \\
Certainty
\end{tabular} \\
\hline $\begin{array}{l}\text { Management } \\
\text { understanding } \\
\text { and attitude }\end{array}$ & $\begin{array}{l}\text { No } \\
\text { comprehension } \\
\text { of quality as a } \\
\text { management } \\
\text { tool. Tend to } \\
\text { blame quality } \\
\text { department } \\
\text { for "quality } \\
\text { problems". }\end{array}$ & $\begin{array}{l}\text { Recognising } \\
\text { that quality } \\
\text { management may } \\
\text { be of value but } \\
\text { not willing to } \\
\text { provide money or } \\
\text { time to make it all } \\
\text { happen. }\end{array}$ & $\begin{array}{l}\text { While going through } \\
\text { quality improvement } \\
\text { programme learn } \\
\text { more about quality } \\
\text { management; } \\
\text { becoming supportive } \\
\text { and helpful. }\end{array}$ & $\begin{array}{l}\text { Participating } \\
\text { Understand } \\
\text { absolutes of quality } \\
\text { management. } \\
\text { Recognise their } \\
\text { personal role } \\
\text { in continuing } \\
\text { emphasis. }\end{array}$ & $\begin{array}{l}\text { Consider quality } \\
\text { management } \\
\text { as an essential } \\
\text { part of company } \\
\text { system. }\end{array}$ \\
\hline $\begin{array}{l}\text { Quality } \\
\text { organisation } \\
\text { status }\end{array}$ & $\begin{array}{l}\text { Quality is hidden } \\
\text { in manufacturing } \\
\text { or engineering } \\
\text { departments. } \\
\text { Inspection } \\
\text { probably not part } \\
\text { of organisation. } \\
\text { Emphasis on } \\
\text { appraisal and } \\
\text { sorting } \\
\end{array}$ & $\begin{array}{l}\text { A stronger } \\
\text { quality leader is } \\
\text { appointed but } \\
\text { main emphasis is } \\
\text { still on appraisal } \\
\text { and moving the } \\
\text { product. Still part } \\
\text { of manufacturing } \\
\text { or other. }\end{array}$ & $\begin{array}{l}\text { Quality department } \\
\text { reports to top } \\
\text { management, } \\
\text { all appraisal is } \\
\text { incorporated and } \\
\text { manager has role } \\
\text { in management of } \\
\text { company. }\end{array}$ & $\begin{array}{l}\text { Quality manager } \\
\text { is an officer of } \\
\text { company; effective } \\
\text { status reporting } \\
\text { and preventive } \\
\text { action. Involved } \\
\text { with customer } \\
\text { affairs and special } \\
\text { assignments. }\end{array}$ & $\begin{array}{l}\text { Quality manager } \\
\text { on board of } \\
\text { directors. } \\
\text { Prevention is } \\
\text { main concern. } \\
\text { Quality is a } \\
\text { thought leader. }\end{array}$ \\
\hline
\end{tabular}




\begin{tabular}{|c|c|c|c|c|c|}
\hline $\begin{array}{l}\text { Problem } \\
\text { handling }\end{array}$ & $\begin{array}{l}\text { Problems } \\
\text { are fought as } \\
\text { they occur; } \\
\text { no resolution; } \\
\text { inadequate } \\
\text { definition: lots } \\
\text { of yelling and } \\
\text { accusations. }\end{array}$ & $\begin{array}{l}\text { Teams are set up } \\
\text { to attack major } \\
\text { problems. Long- } \\
\text { range solutions } \\
\text { are not solicited. }\end{array}$ & $\begin{array}{l}\text { Corrective action } \\
\text { communication } \\
\text { established. Problems } \\
\text { are faced openly and } \\
\text { resolved in an orderly } \\
\text { way. }\end{array}$ & $\begin{array}{l}\text { Problems are } \\
\text { identified early in } \\
\text { their development. } \\
\text { All functions are } \\
\text { open to suggestion } \\
\text { and improvement. }\end{array}$ & $\begin{array}{l}\text { Except in the } \\
\text { most unusual } \\
\text { cases, problems } \\
\text { are prevented. }\end{array}$ \\
\hline $\begin{array}{l}\text { Cost of quality } \\
\text { as } \% \text { of sales }\end{array}$ & $\begin{array}{l}\text { Reported: } \\
\text { Unknown Actual; } \\
20 \%\end{array}$ & $\begin{array}{l}\text { Reported: } 3 \% \\
\text { Actual; } 18 \%\end{array}$ & $\begin{array}{l}\text { Reported: } 8 \% \text { Actual: } \\
12 \%\end{array}$ & $\begin{array}{l}\text { Reported: } 6.5 \% \\
\text { Actual: } 8 \%\end{array}$ & $\begin{array}{l}\text { Reported: } 2.5 \% \\
\text { Actual: } 2.5 \%\end{array}$ \\
\hline $\begin{array}{l}\text { Quality } \\
\text { improvement } \\
\text { actions }\end{array}$ & $\begin{array}{l}\text { No organised } \\
\text { activities. No } \\
\text { understanding of } \\
\text { such activities }\end{array}$ & $\begin{array}{l}\text { Trying obvious } \\
\text { "motivational" } \\
\text { short-range } \\
\text { efforts. }\end{array}$ & $\begin{array}{l}\text { Implementation of a } \\
\text { multi-step programme } \\
\text { (e g. Crosby's 14- } \\
\text { step) with thorough } \\
\text { understanding and } \\
\text { establishment of each } \\
\text { step. }\end{array}$ & $\begin{array}{l}\text { Continuing } \\
\text { the multi-step } \\
\text { programme and } \\
\text { starting other pro- } \\
\text { active / preventive } \\
\text { product quality } \\
\text { initiatives. }\end{array}$ & $\begin{array}{l}\text { Quality } \\
\text { improvement } \\
\text { is a normal } \\
\text { and continued } \\
\text { activity. }\end{array}$ \\
\hline $\begin{array}{l}\text { Summary } \\
\text { of company } \\
\text { quality } \\
\text { posture }\end{array}$ & $\begin{array}{l}\text { "We don't know } \\
\text { why we have } \\
\text { problems with } \\
\text { quality". }\end{array}$ & $\begin{array}{l}\text { "Is it absolutely } \\
\text { necessary to } \\
\text { always have } \\
\text { problems with } \\
\text { quality?" }\end{array}$ & $\begin{array}{l}\text { "Through management } \\
\text { commitment and } \\
\text { quality improvement } \\
\text { we are identifying } \\
\text { and resolving our } \\
\text { problems." }\end{array}$ & $\begin{array}{l}\text { "Defect prevention } \\
\text { is a routine part of } \\
\text { our operation." }\end{array}$ & $\begin{array}{l}\text { "We know why } \\
\text { we do not have } \\
\text { problems with } \\
\text { quality." }\end{array}$ \\
\hline
\end{tabular}

Source: Crosby P., (1979). Quality Is Free: The Art of Making Quality Certain, McGraw-Hill, New York.

\section{Research Methodology}

Based on the presented theoretical framework of the quality management system, an empirical research is conducted among economic entities within the dairy industry on the territory of the Republic of Serbia. The data were collected through a questionnaire and interview method. Structured questionnaire consisting of three parts. The first part concerned the general information about the company. The second part was related to information on implemented quality management systems and process orientation of the company, which determines the level of maturity of the company. The third part of the questionnaire was about improving the quality of business processes. In this scientific paper, the results of the second part of the questionnaire are presented, covering the following aspects of the quality management system: quality management understanding and attitude, quality organisation status, problem handling, cost of quality as percent of sales, quality improvement actions and summary of company quality posture.

The aim of the paper is to point out the existence of differences in the implementation of the quality management system and maturity level according to the size of the respondents (companies). For this purpose, an empirical survey was conducted, which included a sample of 14 respondents (companies) of different ownership, the number of employees in the company, and different organizational structures from the territory of the Republic of Serbia. According to the form of ownership, the sample consists of 7 limited liability companies $(50.0 \%)$ and 7 joint stock companies $(50.0 \%)$. When it comes to the number of employees (company size), 7 respondents $(50.0 \%)$ have up to 50 employees and belong to the category of small enterprises, 1 respondent $(7.1 \%)$ has 51-250 employees and belongs to the category of medium-sized enterprises and 6 respondents $(42.9 \%)$ have over 250 employees and fall into the category of large 
enterprises. By organizational structure, 8 respondents $(57.1 \%)$ have a functional, while 6 respondents $(42.9 \%)$ have a process oriented structure of the company.

Using a Likert scale, respondents rated six aspects of the quality management system (quality management understanding and attitude, quality organisation status, problem handling, cost of quality as percent of sales, quality improvement actions and summary of company quality posture) with grades from 1 to 5 , whereby a higher grade implies a higher level of maturity of the company. The overall assessment of the quality management system and the level of maturity of the dairy industry was obtained as the sum of the results of each individual aspect. Then, the total score was divided with six (the number of the quality management system aspects).

Based on the analysed theoretical background and appointed objective of the research, the following hypothesis was made:

$H_{1}$ : The implementation of the quality management system and the level of maturity in the dairy industry vary by company size.

Hypothesis testing is provided by the application of Kruskal-Wallis' test. Data processing and testing of the proposed hypothesis were conducted in the statistical software of IBM SPSS version 21.

\section{Research results and Discussion}

The minimum, maximum, mean, standard deviation and variance were used to obtain descriptive statistical indicators of the quality management system (Table 1).

Table 2: Descriptive statistics of quality management system

\begin{tabular}{|l|c|c|c|c|c|c|c|c|}
\hline & $\mathrm{N}$ & $\begin{array}{c}\text { Mini } \\
\mathrm{mum}\end{array}$ & $\begin{array}{c}\text { Maxi } \\
\text { mum }\end{array}$ & Mean & $\begin{array}{c}\text { Std. } \\
\text { Devia } \\
\text { tion }\end{array}$ & Varia nce & $\begin{array}{c}\text { Kolmogorov- } \\
\text { Smirnov }\end{array}$ & $\begin{array}{c}\text { Shapiro- } \\
\text { Wilk }\end{array}$ \\
\hline $\begin{array}{l}\text { Quality } \\
\text { Management } \\
\text { Understanding } \\
\text { and Attitude }\end{array}$ & 14 & 2 & 5 & 3.86 & 1.17 & 1.36 & 0.009 & 0.010 \\
\hline $\begin{array}{l}\text { Quality } \\
\text { Organisation } \\
\text { Status }\end{array}$ & 14 & 1 & 5 & 2.86 & 1.79 & 3.21 & 0.004 & 0.003 \\
\hline Problem Handling & 14 & 1 & 5 & 3.00 & 1.18 & 1.39 & 0.042 & 0.090 \\
\hline $\begin{array}{l}\text { Cost of Quality as } \\
\text { of Sales }\end{array}$ & 14 & 1 & 5 & 3.07 & 1.90 & 3.61 & 0.002 & 0.001 \\
\hline $\begin{array}{l}\text { Quality } \\
\text { Improvement } \\
\text { Actions }\end{array}$ & 14 & 2 & 5 & 3.71 & 1.38 & 1.91 & 0.016 & 0.001 \\
\hline $\begin{array}{l}\text { Summary of } \\
\text { Company Quality } \\
\text { Posture }\end{array}$ & 14 & 3 & 5 & 4.00 & 0.96 & 0.92 & 0.004 & 0.001 \\
\hline $\begin{array}{l}\text { Quality } \\
\text { Management } \\
\text { System }\end{array}$ & 14 & 1.83 & 5.00 & 3.42 & 1.27 & 1.61 & 0.052 & 0.016 \\
\hline
\end{tabular}

Source: Author's calculation, SPSS output table

The range of results obtained is from 1 to 5, while the average value of the aspects is as follows: quality management understanding and attitude 3.86, quality organisation 
status 2.86 , problem handling 3.00 , cost of quality as $\%$ of sales 3.07 , quality improvement actions 3.71 , summary of company quality posture 4.00 . The overall quality management system has an average value of 3.42, which indicates the third level of maturity of the dairy industry. The results of the Kolmogorov-Smirnov and Shapiro-Wilk tests for individual aspects and the quality management system indicate that the assumption of normality of distribution is not confirmed, i.e. the magnitude of significance is less than 0.05 , which requires the use of non-parametric statistical techniques.

Determining the difference in the implementation of the quality management system and the level of maturity in relation to the size of the company was investigated using the Kruskal-Wallis test (Table 2), as a non-parametric alternative to one-way analysis of variance of different groups.

The Kruskal-Wallis test is used to compare the results of a continuous variable individual aspects and a total quality management system for three or more groups of company size (up to 50 employees, 51-250, over 250). When the significance level is less than 0.05 , it is concluded that the difference in the obtained values of the continuous variable between the groups is significant (Coakes, 2013, p. 202). Then accompanying research (Table 3) is applied, which, most often, involves converting the results into ranks, and comparing mean values of ranks and medians (Green, M., Salking, N., 2014, p. 410).

Table 3: Test Statistics ${ }^{a, b}$

\begin{tabular}{|l|c|c|c|c|c|c|c|}
\hline & $\begin{array}{c}\text { Quality } \\
\text { Management } \\
\text { anderstanding Attitude }\end{array}$ & $\begin{array}{c}\text { Quality } \\
\text { Organisation } \\
\text { Status }\end{array}$ & $\begin{array}{c}\text { Problem } \\
\text { Handling }\end{array}$ & $\begin{array}{c}\text { Cost of } \\
\text { Quality as \% } \\
\text { of Sale }\end{array}$ & $\begin{array}{c}\text { Quality } \\
\text { Improvement } \\
\text { Actions }\end{array}$ & $\begin{array}{c}\text { Summary of } \\
\text { Company } \\
\text { Quality } \\
\text { Posture }\end{array}$ & $\begin{array}{c}\text { Quality } \\
\text { Management } \\
\text { System }\end{array}$ \\
\hline Chi-Square & 11.361 & 11.361 & 11.197 & 7.533 & 7.563 & 5.185 & 10.539 \\
df & 2 & 2 & 2 & 2 & 2 & 2 & 2 \\
Asymp. Sig. & .003 & .003 & .004 & .023 & .023 & .075 & .005 \\
\hline
\end{tabular}

\section{Source: Author's calculation, SPSS output table}

The Kruskal-Wallis test revealed a statistically significant difference in quality management understanding and attitude according to company size ( $\mathrm{Gp} 1, \mathrm{n}=7$ : up to 50, $\mathrm{Gp} 2, \mathrm{n}=1: 51-250, \mathrm{Gp} 3, \mathrm{n}=6), \mathrm{c} 2(2, \mathrm{n}=14)=11.361, \mathrm{p}=0.003$. Quality management understanding and attitude is at the highest level in companies with over 250 employees $($ Mean Rank $=11.50, \mathrm{Md}=5.0)$, and at the lowest level in companies with up to 50 employees (Mean Rank = 4.07, Md=3.0).

The Kruskal-Wallis test revealed a statistically significant difference in the quality organisation status according to company size ( $\mathrm{Gp} 1, \mathrm{n}=7$ : up to $50, \mathrm{Gp} 2, \mathrm{n}=1$ : 51 $250, \mathrm{Gp} 3, \mathrm{n}=6), \mathrm{c} 2(2, \mathrm{n}=14)=11.361, \mathrm{p}=0.003$. Quality organisation status is at the highest level in companies with over 250 employees (Mean Rank $=11.50, \mathrm{Md}=5.0$ ), and at the lowest level in companies with up to 50 employees (Mean Rank $=4.07$, Md $=1.0$ ).

The Kruskal-Wallis test revealed a statistically significant difference in problem handling according to company size $(\mathrm{Gp} 1, \mathrm{n}=7$ : up to $50, \mathrm{Gp} 2, \mathrm{n}=1$ : 51-250, Gp3, 
$\mathrm{n}=6), \mathrm{c} 2(2, \mathrm{n}=14)=11.197, \mathrm{p}=0.004$. Problem handling is at the highest level in companies with over 250 employees (Mean Rank $=11.50, \mathrm{Md}=4.0$ ), and at the lowest level in companies with up to 50 employees (Mean Rank=4.07, Md=2.0).

The Kruskal-Wallis test revealed a statistically significant difference in cost of quality as $\%$ of sales according to company size (Gp1, $\mathrm{n}=7:$ to $50, \mathrm{Gp} 2, \mathrm{n}=1: 51-250$, Gp3, $n=6)$, c2 $(2 . n=14)=7.533, p=0.023$. Cost of quality as $\%$ of sales are at the highest level in companies with over 250 employees (Mean Rank $=10.67, \mathrm{Md}=5.0$ ), and at the lowest level in companies with up to 50 employees (Mean Rank $=4.71, \mathrm{Md}$ $=1.0$ ).

Table 4: Ranks and median

\begin{tabular}{|c|c|c|c|c|}
\hline $\begin{array}{l}\text { Aspects and Overall } \\
\text { Quality Management } \\
\text { System }\end{array}$ & $\begin{array}{c}\text { Number of } \\
\text { employees } \\
\text { (company size) }\end{array}$ & $\mathrm{N}$ & Mean Rank & Median \\
\hline \multirow{4}{*}{$\begin{array}{l}\text { Quality Management } \\
\text { Understanding and } \\
\text { Attitude }\end{array}$} & Up to 50 & 7 & 4,07 & 3,00 \\
\hline & $51-250$ & 1 & 7,50 & 4,00 \\
\hline & Over 250 & 6 & 11,50 & 5,00 \\
\hline & Total & 14 & & \\
\hline \multirow{4}{*}{ Quality Organisation Status } & Up to 50 & 7 & 4,07 & 1,00 \\
\hline & $51-250$ & 1 & 7,50 & 3,00 \\
\hline & Over 250 & 6 & 11,50 & 5,00 \\
\hline & Total & 14 & & \\
\hline \multirow{4}{*}{ Problem Handling } & Up to 50 & 7 & 4,07 & 2,00 \\
\hline & $51-250$ & 1 & 7,50 & 3,00 \\
\hline & Over 250 & 6 & 11,50 & 4,00 \\
\hline & Total & 14 & & \\
\hline \multirow{4}{*}{$\begin{array}{l}\text { Cost of Quality as \% of } \\
\text { Sales }\end{array}$} & Up to 50 & 7 & 4,71 & 1,00 \\
\hline & $51-250$ & 1 & 8,00 & 4,00 \\
\hline & Over 250 & 6 & 10,67 & 5,00 \\
\hline & Total & 14 & & \\
\hline \multirow{4}{*}{$\begin{array}{l}\text { Quality Improvement } \\
\text { Actions }\end{array}$} & Up to 50 & 7 & 4,79 & 2,00 \\
\hline & $51-250$ & 1 & 7,00 & 4,00 \\
\hline & Over 250 & 6 & 10,75 & 5,00 \\
\hline & Total & 14 & & \\
\hline \multirow{4}{*}{$\begin{array}{l}\text { Summary of Company } \\
\text { Quality Posture }\end{array}$} & Up to 50 & 7 & 5,21 & 3,00 \\
\hline & $51-250$ & 1 & 11,50 & 5,00 \\
\hline & Over 250 & 6 & 9,50 & 5,00 \\
\hline & Total & 14 & & \\
\hline \multirow{4}{*}{$\begin{array}{l}\text { Quality Management } \\
\text { System }\end{array}$} & Up to 50 & 7 & 4,00 & 2,00 \\
\hline & $51-250$ & 1 & 8,00 & 3,83 \\
\hline & Over 250 & 6 & 11,50 & 4,58 \\
\hline & Total & 14 & & \\
\hline
\end{tabular}

Source: Author's calculation, SPSS output table

The Kruskal-Wallis test revealed a statistically significant difference in quality improvement actions according to company size (Gp1, $\mathrm{n}=7$ : up to 50, Gp2, $\mathrm{n}=1$ : 51 - 
250, Gp3, $\mathrm{n}=6), \mathrm{c} 2(2, \mathrm{n}=14)=7.563, \mathrm{p}=0.023$. Quality improvement actions are at the highest level in companies with over 250 employees (Mean Rank $=10.75, \mathrm{Md}=$ 5.0 ), and at the lowest level in companies with up to 50 employees (Mean Rank $=4.79$, $\mathrm{Md}=2.0$ ).

The Kruskal-Wallis test did not reveal a statistically significant difference in the summary of company quality posture according to the size of the company (Gp1, $\mathrm{n}=7$ : to $50, \mathrm{Gp} 2, \mathrm{n}=1: 51-250, \mathrm{Gp} 3, \mathrm{n}=6), \mathrm{c} 2(2, \mathrm{n}=14)=5.185, \mathrm{p}=0.075>0.05$.

The Kruskal-Wallis test revealed a statistically significant difference in the implementation of quality management system according to company size $(\mathrm{Gp} 1, \mathrm{n}=7$ : up to $50, \mathrm{Gp} 2, \mathrm{n}=1: 51-250, \mathrm{Gp} 3, \mathrm{n}=6), \mathrm{c} 2(2, \mathrm{n}=14)=10.539, \mathrm{p}=0.005$. The quality management system is most implemented in companies with over 250 employees (Mean Rank $=11.50, \mathrm{Md}=4.58$ ) and at least in companies with up to 50 employees (Mean Rank $=4.00, \mathrm{Md}=2.0)$. At the same time, this implies that large companies have the highest level of maturity, while small companies have the lowest level of maturity.

Considering that in five of the six aspects of the quality management system, as with the overall quality management system, are determined a significant difference compared to the size of company, it may be noted that the proposed assumption of $\mathrm{H}_{1}$ is accepted.

\section{Conclusion}

Empirical research has performed calculations of the level of maturity of the quality management system for individual organizations based on the QMMG model. KruskalWallis test compares the results of quality management systems variable (individual aspects) and based on statistically significant deviations in five of the six aspects it can be argued that the starting hypothesis The implementation of the quality management system and the level of maturity in the dairy industry vary by company size is proven. Additional analysis of the results obtained by the research found that the most significant deviations are in aspects of Cost of Quality as\% of Sales and Quality Improvement Actions.

Considering that all enterprises covered by this research apply the ISO 9001 standard and that due to the characteristics of their products they also apply other standards ISO 14000, ISO 22000, ISO 45000, with the latest revisions of the standards ISO 9001: 2015, ISO 14001: 2015, ISO 22000: 2018, ISO $45001: 2018$ the application of these standards is greatly facilitated by creating the possibility of creating an integrated management system. In addition to easier integration with other management systems thanks to the same high-level structure, identical basic text as well as common terms with key definitions, a reduction in quality costs should be expected.

Most of the enterprises covered by this research are based on a fairly traditional organizational culture. In order to achieve better results, it is necessary to improve the management, which would encourage participative organizational culture. In order for the process of continuous improvement to work, it is necessary that the value systems of quality management be built into the entire structure of the organization because it requires the full participation and commitment of all employees. Continuous quality improvement of business processes should contribute to the increase of the efficiency, productivity and profitability of their performance. In that way, it directly affects the improvement of the 
overall performance of the organization, and thus the realization of higher profits, as well as long-term growth.

Based on the conducted research, it can be stated that the applied maturity model has proven to be valuable in measuring the level of maturity of the quality management system. The model presented in this paper and applied in the research can be useful to managers when measuring the level of maturity of their own quality management system. Using this model, many aspects of the quality management system within the organization can be analysed and compared, which makes this model a useful tool for comparison with others in terms of the level of maturity of the quality management system.

Even though maturity models represent a kind of map for enterprise management and a guide for the improvement of certain aspects of the quality management system, they should not only be viewed closely related to the improvement of certain segments. It is necessary that the chosen maturity model, above all, has a general organizational focus, instead of just focusing on individual aspects and in that sense provide a common framework for improving company performance that will enable sustainable growth and the company's development as well as better competitiveness in the end.

In that sense, the applied methodology and the results obtained by theoretical and empirical research presented in this paper, should serve to researchers and managers as a basis for further research of the most important factors of maturity and opportunities to improve overall quality in order to improve the business competitiveness regardless of the type of business.

\section{References}

Anderson, J.C.; Rungtusanatham, M.; Schroeder, R.G.; Devaraj, S. (1995) A path analytic model of a theory of quality management underlying the Deming management method: Preliminary empirical findings. Decision Sciences 26, 637-658.

Coakes, S. (2013). SPSS 20.0 for Windows: Analysis without anguish. New Jersey: Wiley Publishin, Inc.

Crosby P., (1979). Quality Is Free: The Art of Making Quality Certain, McGraw-Hill, New York.

Fisher D., (2004). The Business Process Maturity Model - a practical approach to identifying opportunities for optimization, In: Business Process Trends, 9(4), p. 11-15.

Flynn, B.B.; Schroeder, R.G.; Sakakibara, S. A framework for quality management research and an associated measurement instrument. J. Oper. Manag. 1994, 11, p 339-366.

Green, M., Salking, N. (2014). Using SPSS for Windows and Macintosh: Analyzing and Understanding Data. New York: Pearson Education, Inc.

Hammer M., (2007). The Process Audit, In: Harvard Business Review, 85(4), p. 111 123.

Harmon P., (2004). Evaluating an Organization's Business Process Maturity. In: Business Process Trends, 2(3), p. 1-11. 
Lee J., Lee D., Sungwon K., (2007). An overview of the Business Process Maturity Model. International Workshop on Process Aware Information System - PAIS, Huang Shan, China

Maull R. S., Tranfield D. R., Maull W., (2003). Factors characterising the maturity of BPR programmes, In: International Journal of Operations \& Production Management, 32(6), p. 596-624.

McCormack K., (2007). Business Process Maturity - Theory and Application, BookSurge

Mihajlović, M., Methods and Techniques of Quality Process Improvement in the Milk Industry in the Republic of Serbia, Ekonomske teme ISSN: 0353-8648 vol. 56 (2) p. 221-238, 2018

Rohloff M. (2009). An Aproach to Assess the Implementation of Business Process Management in Enterprises, 17th European Conference on Information SystemsECIS, Verona, Italy.

Rosemann M., de Bruin T., (2004). Towards a Business Process Management Maturity Model. European Conference of Information Systems - ECIS, Regensburg, Germany.

Rummler-Brache Group (2004). Business Process Management in U.S. Firms Today, A Study Commissioned by Rummler-Brache Group, http://rummler-brache.com/ upload/files/PPI_Research_Results.pdf

Saraph, J.V.; Benson, P.G.; Schroeder, R.G. An Instrument for Measuring the Critical Factors of Quality Management. Decis. Sci. 1989, 20, p 810-829.

Schonberger R., (1986) World Class Manufacturing: The Lessons of Simplicity Applied. Free Press, New York

Stepanov Saša, Stepanov Nemanja, Vukotić Nataša, Quality management of catering services, Ekonomika, Vol. 63, january-march 2017, Društvo ekonomista "Ekonomika" Niš, p. 83-96

Valadao, A.F.C.; Campos, P.H.S.; Turroni, J.B. Relationship between the maturity of continous improvement and the certification of quality management system in automotive sector in Brazil. Indep. J. Manag. Prod. 2013, 1, p 96-110.

Weber C., Curtis B., Gardiner T., (2008). Business Process Maturity Model version 1.0. Needham, MA 